\title{
Battery Charging System Using Sun Tracker with Dual- Axis Based on the Internet of things.
}

\author{
I Wayan Eka Krisna Putra \\ Department of Information \\ Technology \\ Udayana University \\ Badung, Bali, Indonesia
}

\author{
I Nyoman Piarsa \\ Department of Information \\ Technology \\ Udayana University \\ Badung, Bali, Indonesia
}

\author{
Kadek Suar Wibawa \\ Department of Information \\ Technology \\ Udayana University \\ Badung, Bali, Indonesia
}

\begin{abstract}
Sun Tracker System is a device which developed to utilized the sunlight energy maximally by following the movement of sunlight. This sun tracker system is designed because the application of solar cells is still mostly placed statically so that the absorption of sunlight obtained is not optimal. In this system, we use four mini solar system cells that can accept 6 voltages. Solar cells obtain voltage values using a voltage sensor, this voltage sensor is only able to read a maximum voltage of 25 Voltage. The sun tracker system aims to make it easier to determine the voltage position based on the voltage value received by voltage sensor based on the Arduino Uno microcontroller. The result of this system is to be able to find the maximum voltage that will be displayed on a website using the ESP8266 module to determine the amount of voltage received by the solar cell and to know the location of the angular position when receiving voltage.
\end{abstract}

Keywords: Sun Tracker; Solar cell; Arduino; Motor Servo; ESP8266

\section{INTRODUCTION}

The necessary energy is never run out. In this cause, the utilization of fossil is able extant. In addition, fossil energy has adverse impacts such as the environmental pollution of water and land is counted 2,200 in Indonesia villages confront the environmental pollution of land and water. The utilization of energy is also increasing bad effects such as global warming, the alteration of extreme climate, etc. This cause, renewable energy is needed to produce enough energy and enough energy and doesn't have a negative impact on the surrounding environment.

This renewable energy is an energy that starts from the sustainable use of natural energy, for example, is sunlight. The utilization of sunlight has changed into the sun's rays into electrical energy. This statement is able to use solar cells. A solar cell is a tool that can be used as a tool for renewable energy.

The solar cell is a device that has several cells and various types of the component to convert sunlight into electrical energy. The utilization of solar cells has been used in several developing countries. the utilization of solar cells has been used for industrial purposes. But in the installation of this solar cell is manually that is by way of static or in a state of silence. This can be overcome by using a sun tracker system on solar cells.

Sun Tracker is a tool that will developed with the internet of things technology where the sun tracker can follow the sun's movements. This can be done to optimize the absorption of solar energy and can store the voltage into the battery to the maximum. The utilization of solar energy in its development will produce electrical energy and become a backup energy source for the future.

The working principle of this system is sunlight coming from one corner leads to the system then the sun tracker will follow the movement of sunlight. This system requires four mini solar cells and four voltage sensors that are used to read voltage values obtained from sunlight. This value will be used as a reference to run the servo motor to a position that has an average or maximum voltage. Therefore, the sun tracker that has been designed can increase the maximum absorption of solar energy to become renewable electricity.

\section{LITERATURE REVIEW 2.1 Internet of Things}

Internet of things is a technology that uses the internet to control and communicate with various other devices. The Internet of things aims to get the benefits of internet connectivity that is connected continuously. The capabilities that are able using data sharing, remote control, and others.

In essence, the Internet of things leads to a component that can be uniquely identified to represent virtually in an Internetbased structure. The word Internet of things was originally proposed by Kevin Ashton in the 1999 era and began to be known through the Auto-ID Center research held at MIT. Based on analysis from the McKinsey Global Institute, the Internet of things is the latest technology that allows users to interact with machines, tools, and other electronic objects with the help of network sensors and actuators to enable machines to get the latest information that they get as desired.

The Internet of things works by using a programming code where each command of the programming code will produce an interaction between fellow actuators that are mechanically connected without any human intervention at any distance. An Internet network connection is a connection between the two interactions of the actuator, while the user only has the duty to be the maker and manager of the operation of the tool directly.

\subsection{Sun Tracker}

Sun Tracker is a tool that will be made with the internet of things technology where this tool will later do the efficiency of the voltage on the solar cell by following the movement of sunlight to maximize the sunlight obtained from the solar cell. 
The sun tracker system is useful for accumulating the absorption of sunlight energy for sustainable processes, and with the most consistent balance as the Sun's position shifts with the seasons. Except, the greater the absorption rate used, the search for sunlight energy becomes more stable, because the proportion of energy coming from direct sunlight is higher, and areas that have stable energy will take precedence.

\subsection{Arduino}

Arduino is a single-board microcontroller that is open-source, derived from the wiring platform, which is structured to facilitate the use of actuators in various fields. The hardware has a VAR atmospheric processor and software that uses its own programming language.

Arduino is an open-source hardware platform aimed at anyone who wants to make prototypes of interactive electronic equipment based on hardware and software that are easy to learn and easy to use. The Arduino microcontroller is programmed using the Arduino programming language which has syntax similarities with the $\mathrm{C}$ programming language. Because it is open-source, users can download the Arduino hardware scheme and build it.

Arduino has a connection with the ATMega microcontroller formed by Atmel as a base, but there are individuals or companies that make Arduino imitations using other microcontrollers and remain compatible with Arduino at the hardware level. Using flexibility, the program code is uploaded via the bootloader although there are several options for bypassing the bootloader and using the downloader to program the microcontroller directly through the ISP port.

\subsection{ESP8266}

Esp8266 is a Smart on Chip (SoC) device that is formed in small size and uses a few external circuits. Esp8266 can communicate via wifi infrastructure that uses IPv4, TPC / IP, and HTTP protocols. The processor used on the Esp8266 is the Tensilica L106 diamond series, whose speed is 32-bit and has an on-chip SRAM. Esp8266 has wifi radio, CPU, Memory, Flash, and peripheral interfaces. Esp8266 also has the ability to be used stand-alone or as an access point for a microcontroller.

\subsection{Servo Motor}

Servo motor is a Direct Current motor device that can do feedback on the close position of the motor which will then be explained again into the control circuit contained in the servo motor. Servo motors consist of several gear circuits, potentiometers and control circuits. The potentiometer has a function used to ensure the angle limit of the servo motor movement. Although the angle of the axis of the servo motor is set based on the results of the pulse value sent through the microcontroller of the servo motor cable .

\subsection{Voltage Sensors}

The voltage sensor is a sensor produced by suppressing the resistance value of an electrical circuit. The voltage sensor takes a voltage value from an electrical circuit that is read using a microcontroller to determine the value of the voltage received by the electrical circuit.

\subsection{Solar Cell}

A solar cell is the role of electricity that can convert sunlight into electrical energy. Solar cells described as photovoltaic in addition to electrical energy solar cells can also be used as a photodetector (infrared detector) or detect electromagnetic radiation. The characterize of Solar cells on absorbing electromagnetic radiation that is received as a semi-conductor that can receive photons from sunlight and convert them into electricity.

Most solar cells are made of pieces of silicon coated with special chemicals to form the basis of these solar cells. Solar cells basically have the smallest thickness of about $0.3 \mathrm{~mm}$ which is divided from several semiconductor materials, each of which is found as a positive type semiconductor and a negative type semiconductor as shown in the following Figure 1.

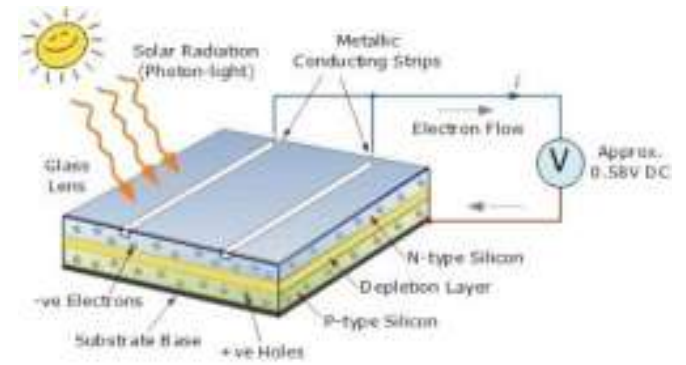

Figure 1 Solar cell

(Source:https://i0.wp.com/www.electricalengineering123.com /wpcontent/uploads/2018/08/construction-of-solarcell.jpg?resize $=452 \% 2 \mathrm{C} 250 \& \mathrm{ssl}=1$ )

Figure 1 is a way of working solar cells that can convert directly to sunlight that is converted into electrical energy. Solar radiation is referred to like the main character to be able to maximize the amount of potential sunlight energy received by solar cells to the earth, in addition to being used to produce electrical energy, the energy produced by the sun can also optimize its thermal energy through the solar thermal system.

\section{RESEARCH METHOD}

In this study, a battery charging system uses a sun tracker with Dual-Axis based on the internet of things that were developed to be able to produce renewable energy. This system consists of a voltage sensor to detect the voltage value received by the solar cell and the servo motor is used to drive the solar cell. The system is designed using four mini solar cells that can receive a voltage of $6 \mathrm{~V}$. This system uses a battery as the storage of electricity generated by solar cells. The sun tracker system can be used to be able to monitor the voltage received by the solar cell and can find out the voltage position with a maximum voltage value which will then be displayed on the website. Following is an overview to build a battery charging system using a sun tracker with dual-axis based on internet of things as follows:

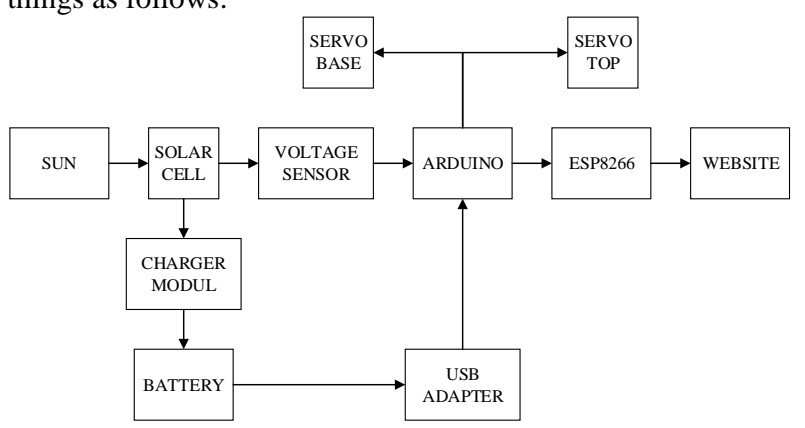

Figure.2 General Description 


\subsection{Concatenation Analysis}

Concatenation analysis is a component design that begins by determining the tools is used based on existing theories in accordance with the literature review is used in this study. The following are tools and materials used in designing battery charging systems using a sun tracker with dual-axis internetbased things as follows:

Table 1. Tools and Materials

\begin{tabular}{|c|c|c|}
\hline No & Tools and Materials & Function \\
\hline 1 & 1 Arduino Uno Module & $\begin{array}{l}\text { a system controller module } \\
\text { with the Arduino Uno } \\
\text { microcontroller. }\end{array}$ \\
\hline 2 & 1 USB Adapated & $\begin{array}{l}\text { a liaison with media that } \\
\text { requires power. }\end{array}$ \\
\hline 3 & 2 Servo Motors & a solar cell drive. \\
\hline 4 & $\begin{array}{l}4 \text { Pieces of Solar Panel } \\
6 \mathrm{~V}\end{array}$ & $\begin{array}{ll}\text { a component that can } \\
\text { convert sunlight } \\
\text { electrical energy. }\end{array}$ \\
\hline 5 & 1 Breadboard & $\begin{array}{l}\text { an electronic circuit that } \\
\text { connects with other } \\
\text { components. }\end{array}$ \\
\hline 6 & 4 Voltage Sensors & $\begin{array}{l}\text { Set the voltage } \\
\text { from } \\
\text { Arduino to solar cell. }\end{array}$ \\
\hline 7 & 1 Soldering iron & to installing the components. \\
\hline 8 & Cable Jumper & a link between components. \\
\hline 9 & 2 Battery Holder & a battery co. \\
\hline 10 & 2 Battery 18650 & a power of storage. \\
\hline 11 & $\begin{array}{lrl}1 & \text { Module } & \text { Wifi } \\
\text { ESP8266 } 01 & \\
\end{array}$ & $\begin{array}{l}\text { a link between solar panels } \\
\text { and the website. }\end{array}$ \\
\hline 12 & 1 Module USB Charger & $\begin{array}{l}\text { a connector of the solar } \\
\text { panel to the battery. }\end{array}$ \\
\hline 13 & 4 Dioda & rectification of electricity. \\
\hline 14 & $\begin{array}{l}3 \text { LED (Red, Yellow, } \\
\text { Orange) }\end{array}$ & $\begin{array}{l}\text { indicators that indicate the } \\
\text { system is running. }\end{array}$ \\
\hline 15 & 3 Resistor $330 \mathrm{Ohm}$ & $\begin{array}{l}\text { as current dividers in the } \\
\text { circuit. }\end{array}$ \\
\hline
\end{tabular}

Table 1 is a tool and material used in designing this study which was implemented as an initial step to build a battery charging system using a sun tracker with Internet-based DualAxis of things.

\subsection{Block Diagram}

The results of the circuit analysis are translated into a circuit model design or layout scheme by designing a system block diagram. The following is the design of a block diagram to build a sun tracker with dual-axis based on the internet of things as follows.

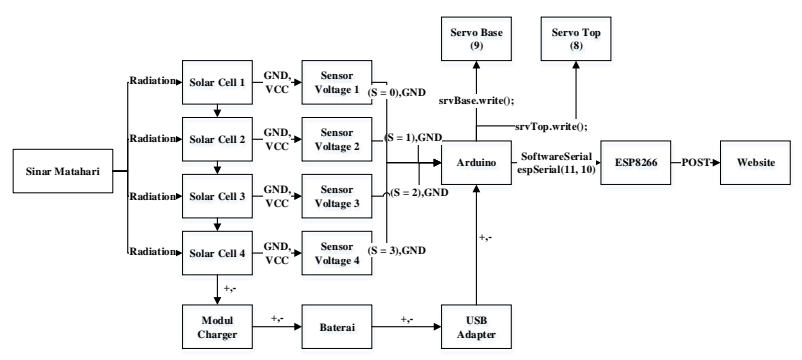

Figure.3 Block diagram of the system

Figure 3 is a block diagram of the system, the solar cell receives radiation from the sun and then produces a voltage which will be received by the voltage sensor. Voltage sensor will accept the voltage generated by the solar cell to determine the value of the voltage received by the solar cell, the results of the sensor are used as a reference to drive the servo motor that is connected to Arduino, then the results of the voltage sensor and servo motor will be displayed on the website using the WiFi internet network.

\subsection{Hardware Design}

Hardware design is the stage of the shape of hardware that is used both in gluing to soldering of the components to be used when assembling the entire system. Here is a hardware design on a battery charging system using a sun tracker with DualAxis based on internet of things is as follows.

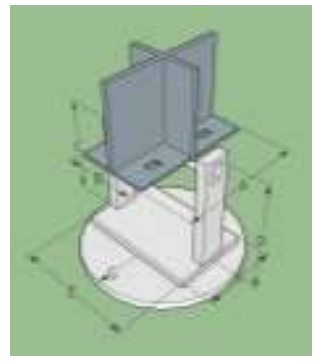

(a)

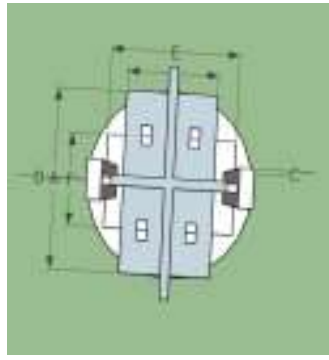

(b)
Figure. 4 (a) Side View, (b) Top View

The hardware design used was designed using the SketchUp 2018 application. This prototype has a size to meet the needs needed in making this research system for $\mathrm{A}$ in the picture has a size of $23 \mathrm{~cm}, \mathrm{~B}$ with a size of $13 \mathrm{~cm}, \mathrm{C}$ with a size of 20 $\mathrm{cm}$, D with a size $24 \mathrm{~cm}, \mathrm{E} 23.5 \mathrm{~cm}, \mathrm{~F} 7 \mathrm{~cm}$, and $\mathrm{G} 31.2 \mathrm{~cm}$ in diameter.

\subsection{Schematic Design}

The results of the hardware design that has been done then the system are translated into a schematic design that functions to connect the device to other devices. The following is a schematic or wiring design on a battery charging system using a sun tracker with Internet-based Dual-Axis of things is as follows.

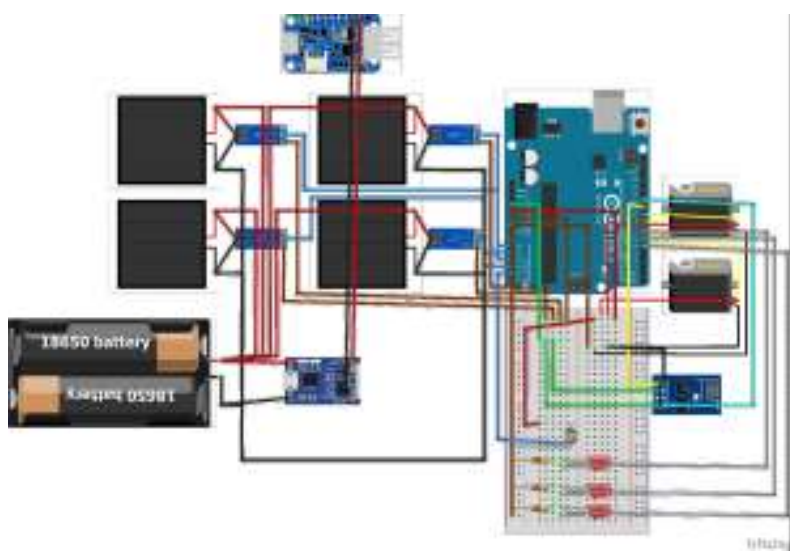

Figure. 5 Schematic Design

\subsection{Mockup Design}

The design of a mockup on a website will not be separated by the design of the User Interface (UI) mockup that can provide a real picture of a website that, if later has been applied as a 
program for monitoring. The following is a form of a mockup in this research system as follows.

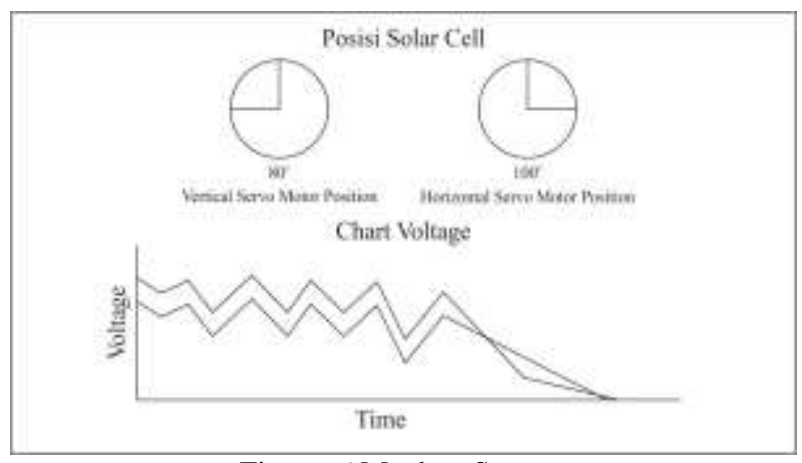

Figure. 6 Mockup System

Figure 6 is a mockup website design that will later display information about the graph of the amount of voltage, vertical servo motor position, horizontal servo motor position and based on the time the data is obtained.

\section{RESULTS AND DISCUSSION}

\subsection{System Implementation}

The system implementation is carried out to implement the design of the system that has been designed to build a real prototype of the system so that the system is ready to use. The following is the hardware design of the prototype battery charging system using the Sun tracker with Dual-Axis based on the internet of things as follows.

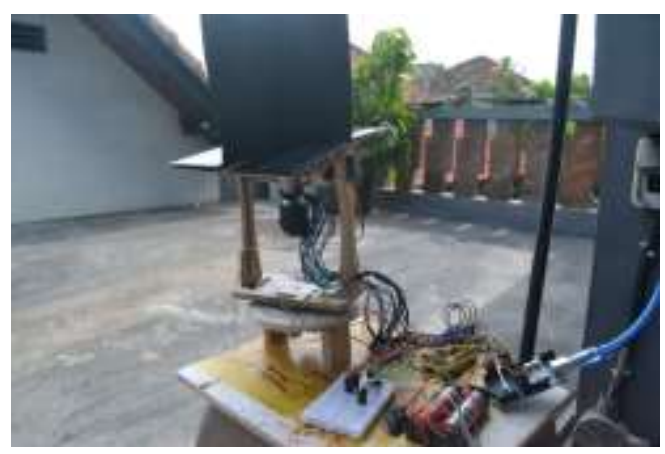

Figure. 7 Result of hardware design

Figure 7 is the result of hardware design on the battery charging system using a sun tracker with Dual-Axis based on the internet of things. This prototype uses four mini solar cells, four voltage sensors, 18650 battery type, Arduino Uno microcontroller, two servo motors, and an ESP8266 wifi module. To process the system charger using a charging module, this charging module is equipped with an indicator light to indicate the battery is charging by indicating a red LED (Figure 8) and the battery is fully charged marked with a blue LED (Figure 8).

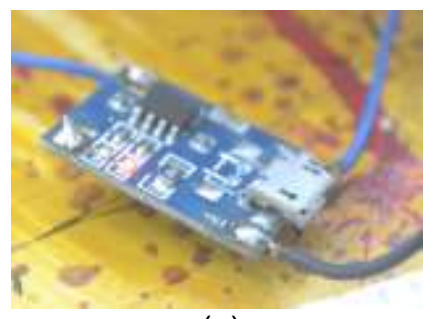

(a)

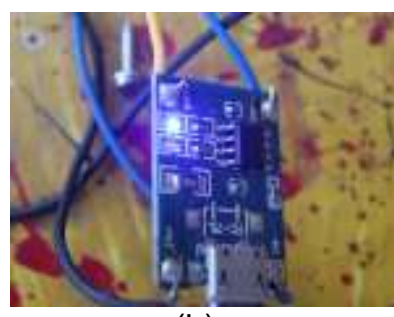

(b)
Figure. 8 (a) Charging the battery, (b) The battery has been charged

\subsection{Testing Tool}

Testing the tool is the most important part to find out whether the system has been running according to predetermined standards. Testing the battery charging system using a sun tracker with Dual-Axis based on the internet of things is done by testing the voltage sensor, testing the movement of the servo motor, and testing the wifi with the ESP8266 module. The following detailed explanation of the testing in this study is as follows.

\subsubsection{Voltage Sensor Testing}

Voltage sensor testing is performed to determine the amount of voltage received by the solar cell by using a voltage sensor. This test uses four solar cells and a voltage sensor to determine the voltage value received by the solar cell. Here is how the voltage sensor testing works as shown in Figure 10 below.

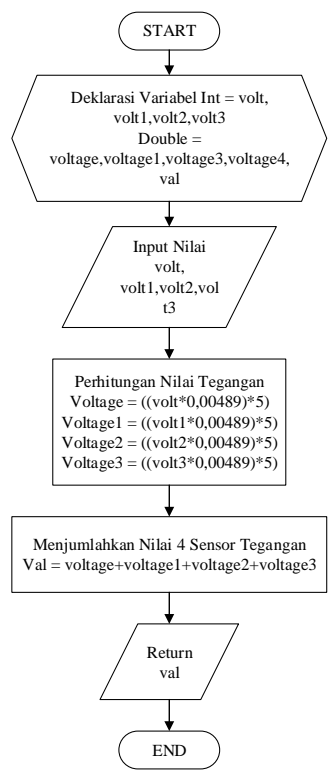

Figure 9 How the Voltage Sensor Test Works

The results of voltage testing using a voltage sensor can be seen using the Arduino serial monitor application in Figure 10 .

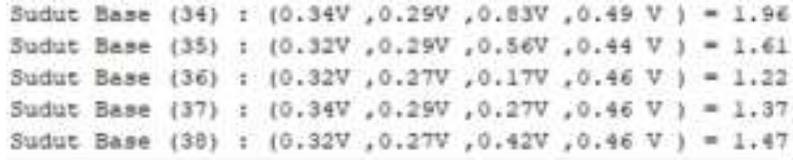

Figure 10 Test Results of Voltage Sensors

\subsubsection{Servo Motor Movement Testing}

Servo motor movement testing is done to determine the movement of the solar cell. Movement testing is used by using 2 servo motors as vertical servo motors and horizontal servo motors. The steps to test this movement are done by determining the initial position, namely the vertical position and horizontal position, which then moves to follow the direction of the sun's rays. Following the results of testing the movement of horizontal servo motors and vertical servo motors can be seen in the Arduino serial monitor in Figure 11 and Figure 12. 


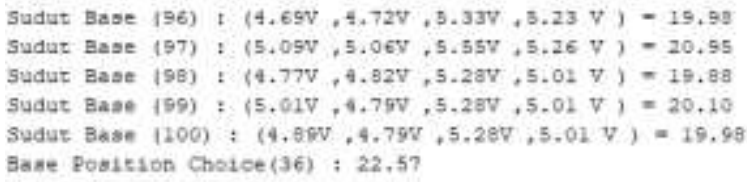

Figure 11 Results of horizontal servo motor movements

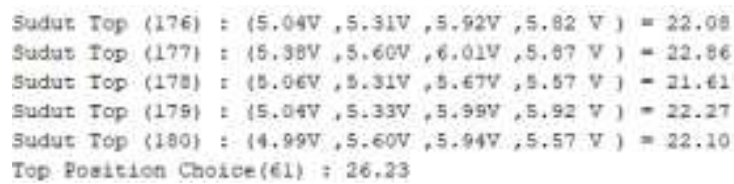

Figure 12 Results of vertical servo motor movements

Figure 11 and Figure 12 is the result of horizontal servo motor testing and vertical servo motor testing which will move each servo motor to the position that has the highest voltage.

After determining the initial position of the system testing the servo motor movement by sun tracker or following the movement of the direction of sunlight. The results of the motion test follow the movement of sunlight which will later divide the voltage to drive the vertical servo motor and horizontal servo motor in an effort to optimize the intensity of sunlight received by the solar cell. The following results from the movement of the sun tracker system can be seen in the Arduino serial monitor application such as Figure 13.

Value Topt $2,18 \mathrm{~V}$

Volve Down 2.21 V

Value Lett: 2,46 .

Value Aleght: $1.83 \mathrm{P}$

Mere to Dosition Wortieal: 114 Degzee, Vasttion Borfaseata1: 100 Degteo

Figure 13 Test Results of the Sun tracker system

\subsubsection{Testing Wifi}

Wifi testing is used to send the voltage data received by the voltage sensor and send the servo motor position data to the website for monitoring. This Wi-Fi testing uses the Wi-Fi module ESP8266 to connect to the internet and send data to the server. Voltage sensor that is at tolerance $(0.2 \mathrm{~V})$ which means that if all values of the voltage divider with a tolerance difference $(0.2 \mathrm{~V})$, the ESP8266 module will send the voltage value and position of the servo motor to the website. The results of the wifi module testing can be seen on the website https://pandan-sari.com/solar/ which will later display the position of the servo motor (Figure 14) and will display a graph with the amount of voltage per hour (Figure 15).

\section{Position Sun Tracker}
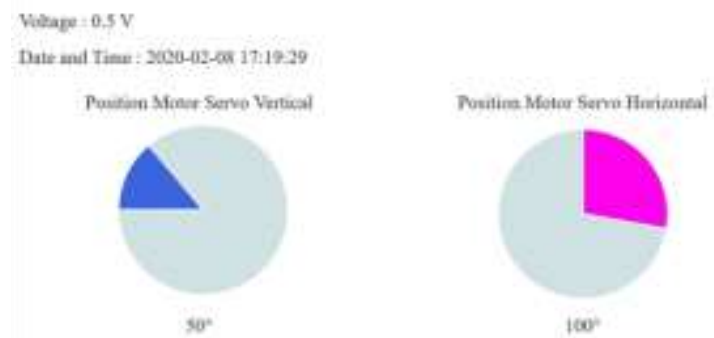

Figure 14 Sun tracker position

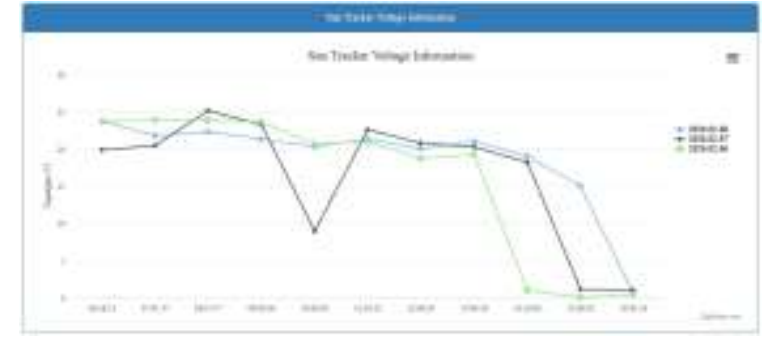

Figure 15 Voltage chart of the sun tracker system

\section{CONCLUSION}

The results of these experiments are able to move the sun tracker system by tracking sunlight with Dual-Axis or twoway. This system can also be monitored by using a website to display voltage data received by a voltage sensor and can display the location of the angular position carried out by a servo motor.

\section{REFERENCES}

[1] J. Bambang Hari Purwoto, Muhamad Alimul F, Ilham Fahmi Huda, "EFISIENSI PENGGUNAAN PANEL SURYA SEBAGAI SUMBER ENERGI ALTERNATIF," Emitor, vol. 18 No. 01.

[2] G. W. Wendryanto, W Sutaya, "PENGEMBANGAN PENGGERAK SOLAR PANEL DUA SUMBU UNTUK MENINGKATKAN DAYA PADA SOLAR PANEL TIPE POLIKRISTAL," Jurnal Jurusan Pendidikan Teknik Mesin (JJPTM), vol. Volume : 8 No : 2, 2017.

[3] N. K. Rizki Waloyo Tricahyono, "SISTEM MONITORING INTENSITAS CAHAYA DAN DAYA PADA DUAL AXIS SOLAR TRACKING SYSTEM BERBASIS IOT," Jurusan Teknik Elektro, vol. Volume 7 Nomor 4, 2018.

[4] I. N. P. I Wayan Pande Agustiana Putra, Kadek Suar Wibawa, "Sistem Pendeteksi Kebakaran Menggunakan Raspberry Pi Berbasis Android," MERPATI, vol. 6, Desember 20182018.

[5] I. K. G. D. P. Putri Isma Oktawiani, Kadek Suar Wibawa, "Sistem Penjemur Pakaian Otomatis Menggunakan Raspberry Pi Berbasis Android," MERPATI, vol. 6, 3 DESEMBER 20182018.

[6] D. Prihatmoko, "PENERAPAN INTERNET OF THINGS ( IoT ) DALAM PEMBELAJARAN DI UNISNU JEPARA," Jurnal SIMETRIS,, vol. 7, pp. 567574, 2016.

[7] F. Djuandi, in PENGENALAN ARDUINO, 2011.

[8] B. T. Ima Maysha, Hasbullah, "PEMANFAATAN TENAGA SURYA MENGGUNAKAN RANCANGAN PANEL SURYA BERBASIS TRANSISTOR 2N3055 DAN THERMOELECTRIC COOLER," ELECTRANS,, vol. VOL.12,, pp. 89 - 96, SEPTEMBER 20132013.

[9] S. P. Elmeki Satria, S. P. Elmeki Satria, Ed. MODUL PEMBELAJARAN MOTOR SERVO. Komplek Kementerian Pendidikan dan Kebudayaan, Gedung E, Lantai 13 Jalan Jenderal Sudirman, Senayan, Jakarta 10270: Direktorat Pembinaan Sekolah Menengah Kejuruan, 2017.

[10] E. I. Team, ESP8266EX Datasheet. www.espressif.com, 2019. 